\title{
ИННОВАЦИОННАЯ НАПРАВЛЕННОСТЬ РАЗВИТИЯ РОССИЙСКОЙ ЭЛЕКТРОЭНЕРГЕТИКИ В КОНТЕКСТЕ МОДЕРНИЗАЦИИ
}

\section{INNOVATIVE DIRECTION \\ OF DEVELOPMENT RUSSIAN \\ ELECTRIC POWER INDUSTRY UNDER THE NEW STRATEGY}

\section{N. Lebedev}

Summary. The content parameters of the Unified energy system of Russia are briefly analyzed. Certain types of products of the Russian electric power industry that have an innovative orientation and require effective modernization structure are considered.

The efficiency of the program of import substitution of equipment, technologies, and domestic producers of electrical equipment is evaluated. The conditions and ways of increasing the efficiency of electric power engineering enterprises that form the search for a new direction of development, based primarily on innovations in the application stage, are defined.

Keywords: innovative system, electric power industry, resource management, import substitution, generating capacity.
$\mathbf{P}$ ынок российской электроэнергетики - один из важнейших рынков народного хозяйства. Его фундамент составляет Единая энергетическая система России (ЕЭС России) как совокупность энергетических объектов, охватывающих обширную часть территории страны в составе систем Дальнего Востока и Сибири, Средней Волги и Юга, Урала, Северо-Запада и Центра в соответствии со сложившимися региональными экономическими пропорциями и потреблением электроэнергии.

Так, в 2018 году было выработано 1 млрд. 055,6 кВт/ч электроэнергии, в 2019 г.- 1 млрд. 080,6 [1], тогда как динамика потребления электроэнергии по энергосистемам распределилась следующим образом: ОЭС Центра $-22,98 \%$, Северо-Запада - 9,0\%, Урала - 24,74\%, Юга - 9,69\%, Средней Волги - 10,44\%, Сибири $19,91 \%$, Дальнего Востока - 3,24\%. Прогнозом спроса на электроэнергию на пятилетие с 2021 по 2025 годы возможный прирост её потребления по сравнению с 2018 г. оценивается в 8,3\%, до 1 млрд. 143,1 кВт/ч. [2].

Конкретные параметры Единой энергетической системы России в текущих условиях определены схемой
Лебедев Никита Андреевич

Д.э.н., nрофессор, в.н.С., ФГБУН Институт экономики Российской академии наук ieras@inecon.org

Аннотация. Кратко проанализированы содержательные параметры Единой энергетической системы России. Рассмотрены отдельные виды продукции российской электроэнергетики, имеющие инновационную направленность, требующие результативной модернизационной структуры.

Дана оценка эффективности Программы импортозамещения оборудования, технологий, отечественных товаропроизводителей электротехнического оборудования. Определены условия и пути наращивания эффективности предприятий электроэнергетического машиностроения, формирующих поиск новой направленности развития, в основе которых лежат в первую очередь инновации в стадии применения.

Ключевые слова: инновационная система, электроэнергетика, управление ресурсами, импортозамещение, генерирующие мощности.

и программой её развития, разработанной и утверждённой в перспективе до 2025 года [3]. Содержательные экономические показатели деятельности субъектов электроэнергетики показывают, что, в частности, в 2019 году на электростанциях страны были введены следующие генерирующие мощности: на ТЭС -1252 МВт; на АЭС 1150 МВт; на ГЭС - 417 МВт; на СЭС и ВЭС - 1382 МВт. [4].

В то же время, перед электроэнергетической отраслью остро стоит необходимость модернизации устаревшего оборудования, не отвечающего современным условиям, преимущесвенно на низкоэффективных ТЭС, старше 40 лет, каких в энергосистеме порядка 60\%, регенерации технологий и подготовки специалистов, в т.ч. и для инновационной сферы, и т.п.

С учётом сложившейся ситуации, Минэнерго на основе Генеральной схемы размещения объектов в объёме до 76 ГВт [5] определило базовые принципы программы технической модернизации энергоблоков в период до 2035 г.

Опять таки, ключевая роль в создании условий технической модернизации электроэнергетических пред- 
Таблица 1. Изменение структуры мощности мировой энергосистемы

\begin{tabular}{|c|c|c|c|}
\hline \multirow{2}{*}{ № п/п } & \multirow{2}{*}{ Источники энергии } & \multicolumn{2}{|c|}{ Доля источников,\% } \\
\hline & & 2016 г. & 2050 г. \\
\hline 1. & Невозобновляемые источники & 68 & 9 \\
\hline 2. & Прочие возобновляемые & 1 & 9 \\
\hline 3. & Гидроэнергетика & 18 & 9 \\
\hline 4. & Ветроэнергетика & 8 & 30 \\
\hline 5. & Гелиоэнергетика & 5 & 43 \\
\hline
\end{tabular}

Источник: данные Института энергетических систем

приятий отводится инновационным проектам, которые должны быть ресурсообеспечены, экологичны, исходить из специфики электроэнергетических предприятий, что при корреляции с совокупностью отдельных мероприятий даст возможность добиться максимальной эффективности от их осуществления.

Структурный характер модернизации электроэнергетических предприятий ориентирован на инновации, обеспечивающие развитие технологий узкоотраслевого потенциала. Нельзя отрицать, что обеспечить конкурентоспособность отечественных технологических разработок на принципах научных достижений для ревальвации эффективности электроэнергетических предприятий призвана в т.ч. и нормативно-законодательная база, фиксирующая на перспективный горизонт научно-технические параметры разработки инновационных технологий и развития рынка модернизируемых энергообъектов [6]. В этом аспекте хотелось бы, прежде всего, отметить правительственную поддержку развития цифровой сертификации электрической энергии; 6 ноября 2019 г. для нашей страны вступило в силу Парижское соглашение, принятое 12 декабря 2015 года на XXI сессии Конференции Сторон Рамочной конвенции ООН по климату, после чего Минэнерго России в соответствии с правительственным Постановлением, а затем и поручением [7] подготовило проект закона «О внесении изменений в Федеральный закон «Об электроэнергетике и отдельные законодательные акты Российской Федерации в связи с введением низкоуглеродных сертификатов» [8]. Законопроектом обусловлено сформировать систему обращения так называемых зелёных или низкоуглеродных сертификатов, которые станут подтверждать факт производства электроэнергии на источниках возобновляемой электроэнергии (ВИЭ) или атомной энергии и станут ещё одним источником инвестиций.

Инновационность же состоит в позитивности эффектов от снижения углеродного следа, показатель которого составляет 515 г. выбросов на 1 кВт ч. произведённой электроэнергии. Анализ показывает, что к 2035 году отечественная электроэнергетика, возможно, повысит углеродоёмкость в 3,5 раза, что снизит несырьевой экспорт, что ещё дальше введёт экономику в зону риска.
Учитывая, что запасы классических энергоресурсов относительно стабилизировалось, во главу угла поставлено рациональное и эффективное использование альтернативных гелиоэнергетики и ветроэнергетики, запас которых неисчерпаем. Уже сегодня ресурсы ветряной и солнечной энергии обеспечивают промышленность и население электричеством. В Дании на ветряных электростанциях (ВЭС) в 2019 г. вырабатывалось 20\% электричества, в Ирландии - 9\%, в Германии - 7\%.

В России воплощён точечный проект - в районе Кисловодска работает мощная ветроэнергетическая установка. В перспективе совокупная мощность этих источников возрастёт, но, как показывает анализ, у ЕЭС России не видит необходимости в интеграции в сеть с большим количеством ВИЭ как у Дании, Ирландии или Германии.

Но, кроме нормативно-законодательного обеспечения развития энергообъектов, перед субъектами электроэнергетики внутренним спросом поставлены ключевые номенклатурные задачи модернизационного развития, которые могли бы быть решены технико-экономическими компетенциями и системностью применяемых средств энергетического машиностроения.

Одна из задач, поставленных около двух десятилетий назад с запланированными сроками решения, сводилась к необходимости освоить серийное производство газовых турбин до 2010 года. В 2021 году запущена первая газовая турбина ГТД $-110 \mathrm{M}$ и планируется всё же запустить их в серийное производство, чем будет преодолена зависимость от зарубежных технологий. А через два года, как отметил О.П. Токарев (Минпромторг), технологию, возможно, будут тиражировать - предмет производства турбины в серии рассматривается [13].

С учётом того, что да настоящего времени серийное производство газовых турбин большой мощности в нашей стране не развёрнуто, модернизацию, в частности, газовой турбины ГТД-110М проводил с 2014 года центр «Газотурбинные технологии», включающий «Интер РАО», «ОДК-Сатурн» и «Роснано». В итоге КПД установки турбины возросла от изначального уровня в 35,5\% до $37 \%$ 
Таблица 2. Направленность импортозамещения в электроэнергетике

\begin{tabular}{|c|c|c|c|}
\hline \multirow[t]{2}{*}{$\begin{array}{l}\text { № } \\
\text { п/п }\end{array}$} & \multirow[t]{2}{*}{ Группы электротехнического оборудования } & \multicolumn{2}{|c|}{$\begin{array}{l}\text { Показатели доли в закупках } \\
\text { российского } \\
\text { оборудования,\% }\end{array}$} \\
\hline & & 2019 г. & 2030 г. \\
\hline 1. & Силовые трансформаторы, автотрансформаторы 110-750 кВ & 70 & \multirow{8}{*}{$\begin{array}{l}95 \% \\
\text { В соответствии } \\
\text { с Энергетической стратегией } \\
\text { России на период } \\
\text { до } 2030 \text { года }\end{array}$} \\
\hline 2. & Шунтирующие реакторы 110-750 кВ & 77 & \\
\hline 3. & $\begin{array}{l}\text { Управляемые шунтирующие реакторы } \\
110-500 \text { кB }\end{array}$ & 64 & \\
\hline 4. & Выключатели 110-750 кВ & 51 & \\
\hline 5. & Разъединители 110-750 кВ & 81 & \\
\hline 6. & Трансформаторы тока 110-500 кB & 57 & \\
\hline 7. & Трансформаторы напряжения 110-500 кB & 41 & \\
\hline 8. & Силовой кабель с изоляцией из сшитого полиэтилена 110-330 кВ & 39 & \\
\hline
\end{tabular}

Источник: составлено автором по: elec.ru

на первом этапе, а в конструкции комплексного парогазового блока - уже до 52\%. Достигнутый формат улучшит экономическую составляющую установки; будет вполне достаточно текущих тарифов на электроэнергию, рост цен потребителям электроэнергии не грозит. С середины 2019 г. турбину перенесли в серийный блок ПГУ (парогазовых установок) гор. Иваново мощностью 325 МВт., и после подтверждения её безопасности планируют оставить в эксплуатации на Ивановских ПГУ.

Ещё один путь, который обсуждается машиностроителями и энергокомпаниями - перенос технологии зарубежного турбостроения в нашу страну, хотя это непросто: Минпромторгом поставлены жёсткие условия: максимально должны быть локализованы критические компоненты: почти весь лопаточный тракт, литые заготовки, камеры сгорания, системы управления.

Вместе с тем, нельзя не учитывать, что в последнее десятилетие на мировом рынке пользуются большим спросом паросиловые установки с повышенными энергетическими характеристиками, а в нашей стране в программе модернизационного развития тепловой энергетики они стали эксплуатироваться с 2005 года. Но с учётом отсутствия отечественных, применялись импортные турбины, стоимость услуг по обслуживанию которых постоянно возрастала.

Подобная зависимость, а также санкционное давление потребовали в т.ч. и развития импортозамещения, предусматривающего Энергетической стратегии России на период до 2030 года сокращение доли импортного оборудования [9].

В электроэнергетике запланирована реализация импортозамещения по ряду групп электротехнического оборудования (табл. 2).
Обеспечение развития энергообъектов ориентировано в целом на поступательное производство отечественного электротехнического оборудования, соответственно на модернизацию электротехнической отрасли промышленности и формирование в нашей стране конкурентоспособных предприятий, выпускающих электротехническое оборудование.

В частности, оценка эффективности Программы импортозамещения оборудования, технологий, материалов и систем в ОАО «ФСК ЕЭС» ориентирована на увеличение в закупках объёма отечественного электротехнического оборудования, повышения степени локализации выпуска электротехнического оборудования и увеличения в производстве инновационной продукции, которая разрабатывалась согласно компаниональным проектам ОАО «ФСК ЕЭС» и отечественных товаропроизводителей.

Если анализировать достоинства Программы импортозамещения ОАО «ФСК ЕЭС», то можно охарактеризовать вполне чёткий алгоритм решения проблем импортозимещения, указание в закупках объёма отечественного оборудования. Видимые слабые места - это, безусловно, локальность импортозамещения, обусловленная в целом балансовыми параметрами сетевой компании - так, интерес ОАО «ФСК ЕЭС» направлен на узкий ассортимент электротехнического оборудования - единственно на силовые трансформаторы, разъединители, кабели, средства релейной защиты автоматики, выключатели, и т.п. сетей с напряжением 110-750 кВ. А импортозамещение электротехнической продукции, используемой в сетях низкого и средне-низкого напряжения, в т.ч., установки по компенсации реактивной мощности сетей 6-10 кВ., делегировано сетевым организациям и бизнес структурам, которые подключили свои предприятия к сетям напряжения 0,4-10 кВ. 
Между тем, с учётом неослабевающего интереса к импортозамещению и необходимости решения проблемы, в перспективе вполне можно увидеть замену импортных установок, комплектующих и оборудования на отечественном рынке электротехнической продукции на отечественную продукцию, при том, что российские предприятия имеют наработки и потенциал производства подобной продукции, а многие из отечественных компонентов (в частности, установки компенсации реактивной мощности и плёночные конденсаторы) даже без государственной поддержки уже много лет успешно конкурируют с импортным электротехническим оборудованием.

Опять таки, раскрывая проблему импортозамещения, О.П. Токарев (Минпромторг) выразил уверенность, что «собственные компетенции в турбиностроении выведет нашу страну на уровень высокотехнологической державы» [10]. И уже имеются видимые результаты модернизации генерирующего оборудования. В каче- стве базового было предложено использовать Постановление № 719 от 17 июля 2015 г. «О подтверждении производства промышленной продукции на территории Российской Федерации» [11], в котором изложены критерии, разрешающие считать оборудование отечественным. В нём перечислены практически все виды оборудования,- и газовые и паровые турбины, котельное оборудование, генераторы, прочее оборудование. Процедуру получения заключения Минпромторга прошло, в частности, новосибирское НПО «Элсиб» ПАО, получившее заключение о подтверждении производства промышленной продукции на территории РФ - завод изготавливает экологичное, ресурсообеспеченное оборудование с учётом специфики ТЭС, ТЭЦ, ГЭС, ГРЭС, АЭС [12].

Чтобы достичь более высоких результатов в модернизации энергетического машиностроения, важно добиться его конкурентоспособности, а стратегия отрасли должна опираться на чёткие ориентиры развития.

\section{ЛИТЕРАТУРА}

1. Отчёт 0 функционировании ЕЭС России в 2019 году // Системный оператор единой энергетической системы. Табл. 1.2. - С. 6.

2. Схема и программа развития Единой энергетической системы России на 2019-2025 годы» // Утв. Приказом Минэнерго России № 174 от 28 февраля 2019 г.- С. 4-5; 27.

3. Приказ Министра энергетики РФ № 174 от 28 февраля 2019 г. «0б утверждении схемы и программы развития Единой энергетической системы России на 2019-2025 годы» // minenergo.gov.ru

4. Схема и программа развития Единой энергетической системы России на 2019-2025 годы» / Утв. Приказом Минэнерго России № 174 от 28 февраля 2019 г. C. 52. // minenergo.gov.ru

5. Распоряжение Правительства РФ от 09.06.2017 г. № 1209- р «0 Генеральной схеме размещения объектов электроэнергетики до 2035 года»; поручение Президента РФ от 12.12.2017 г. № Пр-2530 // consultant.ru

6. http://www.rushydro.ru/activity/energetika-dalnego-vostoka/stroyki/stroitelstvo-i-modernizatsiya/

7. Постановление Правительства Российской Федерации от 21 сентября 2019 года № 1228 «0 принятии Парижского соглашения»; Поручение Председателя Правительства РФ от 26.10.2019 г. № ДМ-П13-9288 // http: www.pravo.gov.ru

8. Федеральный закон «06 электроэнергетике» № 35-Ф3 от 26.03. 2003 г. и отдельные законодательные акты Российской Федерации в связи с введением низкоуглеродных сертификатов // consultant.ru

9. Энергетическая стратегия России на период до 2030 года // Распоряжение Правительства РФ от 13.11.2009 г. № 1715-р; Приказ Минпромторга России от 31 марта 2015 года № 65306 утверждении «Плана мероприятий по импортозамещению в отрасли энергетического машиностроения и электротехнической промышленности Российской Федерации» // consultant.ru

10. www.kp.ru/daily/27039/4104162/

11. Постановление № 719 от 17 июля 2015 г. «0 подтверждении производства промышленной продукции на территории Российской Федерации» (с изм. на 30 апреля 2020 года) // www.fzakon.ru

12. Elsib.ru/

13. www.tek-all.ru/news/id6198/

14. www.kp.ru/daily/27039/4104162/

15. www.kp.ru/daily/27039/4104162/ 